\title{
Early Pleistocene mammalian fauna of Sarkel (Lower Don River area, Russia): mole voles (Ellobiusini, Arvicolinae, Rodentia)
}

\begin{abstract}
Alexey S. Tesakov
ABSTRACT. Two forms of mole voles are present in the Early Pleistocene fauna of Sarkel. Ellobius (Ellobius) kujalnikensis is represented by scarce remains, which show morphological similarity to Early Pleistocene smaller mole voles of Eastern Europe. More numerous Ellobius (Bramus) tarchancutensis represent the second occurrence of this species in the region. The form from Lower Don area is relatively more hypsodont and has a more complex M3 than the type form from Crimea. The priority of the name Bramus Pomel, 1892 over Afganomys Topachevsky, 1965 is shown.
\end{abstract}

KEY WORDS: mole voles, Ellobius, Bramus, Early Pleistocene, Russia.

Alexey S.Tesakov [tesak@ginras.ru], Geological Institute of the Russian Academy of Sciences, Pyzhevsky per. 7, Moscow 119017, Russia.

\section{Раннеплейстоценовая фауна млекопитающих Саркела (нижний Дон, Россия): слепушонки (Ellobiusini, Arvicolinae, Rodentia)}

\begin{abstract}
А.С. Тесаков
РЕЗЮМЕ. В раннеплейстоценовой фауне местонахождения Саркел найдены две формы слепушонок. Ellobius (Ellobius) kujalnikensis представлен небольшим количеством остатков морфологически сходными с видами номинативного подрода раннего плейстоцена Восточной Европы. Более многочисленные Ellobius (Bramus) tarchancutensis представляет вторую хорошо документированную находку этой группы в регионе. Форма с нижнего Дона относительно более гипсодонтна и имеет более сложный M3, чем типовая форма из Крыма. Показан приоритет названия Bramus Pomel, 1892 над Afganomys Topachevsky, 1965.
\end{abstract}

КЛЮЧЕВЫЕ СЛОВА: слепушонки, Ellobius, Bramus, ранний плейстоцен, Россия.

\section{Introduction}

Mole voles (genus Ellobius) first appeared in the fossil record in Late Pliocene. The oldest occurrences were reported from Kazakhstan and Central Asia (Lytchev \& Savinov, 1974; Zazhigin, 1988) and Northern Caucasus (Tesakov, 2004). In Early Pleistocene Ellobius spread throughout western Asia, south East Europe and North Africa (Topachevsky \& Rekovets, 1982; Tutkova, 1989, Geraads, 2002). The hyperspecialized fossorial mode of life has obscured systematic affinities of Ellobius. Most authorities assign these animals to arvicolines (Hinton, 1926, Kretzoi, 1969, and others), but Gromov \& Polyakov (1977) regarded them as cricetid lineage independent of the main vole radiation. The cuneate scull of Ellobius specialized for digging has no direct matches in voles. Molars of mole voles possess roots and have a very simple structure resembling primitive voles of Early Pliocene. Molars of fossil forms become more vole-like with increase of their geological age. Specifically, fossil Ellobius of Late Pliocene and Early Pleistocene commonly show such characters of Pliocene mimomyoid voles as $\mathrm{Mi}$ momys-ridge and enamel islets in lower $\mathrm{m} 1$. The first phylogenetic study of the group based on nuclear genetic markers confirmed the arvicoline affinities of Ellobius and showed their sister-group relationships with the most advanced vole tribes as Arvicolini and Lagurini (Abramson et al., in press).

Mole voles are rare and relatively poorly studied rodents in fossil assemblages of Eastern Europe. Recently, new materials on fossil Ellobius have been collected in the Lower Don River area. The Sarkel locality $\left(47^{\circ} 42^{\prime} \mathrm{N}, 42^{\circ} 12^{\prime} \mathrm{E}\right)$ is located in $2 \mathrm{~km}$ NE from the Sarkel settlement (Tsymlyansk District, Rostov Region, Russia). The site is associated with fluviatile deposits exposed in the cliff of the Tsymla Reservoir. It was found in 2001 by Pavel Nikolskii. The first systematic excavation of 2002 yielded abundant material of small and large mammals. The presence of Archidiskodon meridionalis tamanensis Dubrovo, Lagurodon arankae Kretzoi, Prolagurus pannonicus (Kormos), Microtus (Allophaiomys) pliocaenicus Kormos, Mimomys savini Hinton, Clethrionomys hintonianus Kretzoi, and others indicates the Early Pleistocene age of the fauna (Nikolskii \& Tesakov, 2003). Geological studies of the section confirmed the age of the locality based on paleomagnetic characteristics (reversed po- 
larity, apparently Matuyama Chron), palynology, and paleopedology (Dodonov et al., 2007). Excavations of 2002, 2003, 2006, and 2007 brought about four thousand small mammal remains. The rich Sarkel material yielded remains of two forms of mole voles. This new interesting material is described below. The fossils are preserved in the Geological Institute of the Russian Academy of Sciences (Moscow), collection GIN EMM139.

Terminology and abbreviations. Occlusal elements of vole mole molars are named according to van der Meulen (1973). Measurements are after Tesakov (2004). Terms for dentine tracts (sinuous enamel-dentine boundary folds) in dentition of rhizodont voles are after G. Rabeder (1980): $\mathrm{HH}$-index, the square root of the sum of squared heights of dentine tracts of hypoconid and hypoconulid in lower molars; PA-index, the square root of the sum of squared heights of dentine tracts of protocone and anterocone in upper molars; ASD - anterosinuid, HSD - hyposinuid, HSLD hyposinulid, DS - distosinus, AS - anterosinus, ASL anterosinulus, PRS - protosinus. SE - standard error, $\mathrm{SD}$ - standard deviation, CV - coefficient of variation. Lower case $\mathrm{m}$ stands for lower molars; upper case $\mathrm{M}$, for upper molars. T stands for occlusal triangle; AC, anterior cap; $\mathrm{H}$, labial height. All measurements are in $\mathrm{mm}$.

\section{Systematic Paleontology}

Order Rodentia Bowdich, 1821

Family Cricetidae Fischer von Waldheim, 1817

Subfamily Arvicolinae Gray, 1821

Genus Ellobius Fischer von Waldheim, 1814

Subgenus Ellobius Fischer von Waldheim, 1814

Type species: Ellobius talpinus (Pallas, 1770)

Ellobius kujalnikensis Topachevsky, 1965

Fig. 1.

1965a: Ellobius kujalnikensis sp. nov.: V.A. Topachevsky, Nasekomoyadnye i gryzuny...: pp. 97-100, fig.23: 1-2.

1965: Ellobius palaeotalpinus sp. nov.: A.I. Schevtschenko, Opornye kompleksy...: pp. 37-38, fig.18.

1965b: Ellobius kujalnikensis sp. nov.: V.A. Topachevsky, Novi vidi slipushkiv ..., pp. 515-516, fig. 1.

1965b: Ellobius tauricus sp. nov.: V.A. Topachevsky, Novi vidi slipushkiv ..., p. 517, fig. 2 .

1973: Ellobius kujalnikensis progressus subsp. nov.: V.A. Topachevsky, Gryzuny tamanskogo...: pp. 119-124, fig.26: 7-10.

1982: Ellobius palaeotalpinus: Topachevsky et Recovets, Novye materially ..., pp. 47-49, fig. 1 .

1982: Ellobius tiliguliensis: Topachevsky et Recovets, Novye materially ..., pp. 50-51, figs. 1, 2 .

1982: Ellobius tauricus: Topachevsky et Recovets, Novye materially ..., pp. 51 , fig. 1 .

Material. One fragmental $\mathrm{m} 1$, sin: length of anteroconid $0.95, \mathrm{~W}=1.1 ; 1 \mathrm{~m} 3$, dex: $1.6 \times 0.95 ; 1$ fragmental M1, sin: $\mathrm{W}=1.4 ; 1 \mathrm{M} 3$, dex: 1.4 x 0.92 .

Locality and geological age. Sarkel, Rostov Region, Russia. Early Pleistocene, early Biharian, Tamanian faunal assemblage, regional zone MQR8.

Description. This small mole vole has strongly confluent occlusal elements and very low dentine tracts.

Fragmental m1 (Fig. 1) preserves rectangular shaped anteroconid, $\mathrm{T} 2$ and $\mathrm{T} 3$. The anteroconid bears juve-

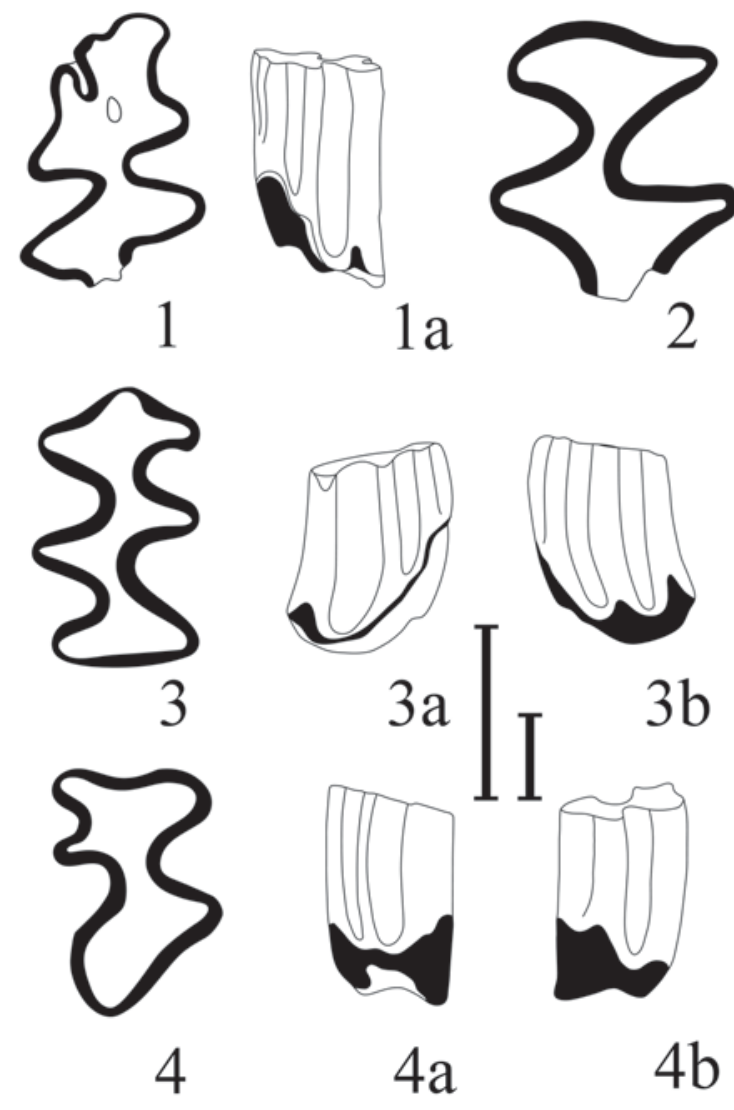

Figure 1. Ellobius kujalnikensis.

1 - fragmental m1, sin, 139/11; 2 - fragmental M1, sin, 139/39; 3 - m3, dex, 139/20, 4 - M3, dex, 139/40 (a - labial view, b lingual view). Scale bars are $1 \mathrm{~mm}$.

nile folds with one of them deeply incutting anterolabially. The anteroconid also bears a distinct primary dentine sign of the enamel islet (Fig. 1: 1). T2 and T3 are broadly confluent. Their connection with the anteroconid is much narrower. The anterosinuid is 1.15 mm high.

The $\mathbf{m} \mathbf{3}$ has moderately confluent, well alternating occlusal elements (Fig. 2). ASD=0.9, HSD=0.6. HSLD= 0.45 .

Fragmental M1 has preserved anterior lobe, and broadly confluent $\mathrm{T} 1$ and $\mathrm{T} 2$. The protocone root is in central position. $\mathrm{AS}=0.5, \mathrm{ASL}=0.55, \mathrm{PRS}=0.5$.

The M3 is bipartite (Fig. 1: 4). The anterior fold and distinct $\mathrm{T} 2$ are separated from the posterior fold by a neck with the dentine communication thicker than width of enamel band. $\mathrm{AS}=0.3$, $\mathrm{PRS}=0.15, \mathrm{H}=1.9$.

Comparison. Ellobius kujalnikensis. The mole vole from the type locality of Kryzhanovka (upper level) shows very similar structure and hypsodonty of $\mathrm{m} 1$ with regard to the Sarkel form. Particularly similar is the robust rectangular anteroconid. Mole voles from Odessa are distinct in well developed Mimomys-ridge. The absence of this character in Sarkel form may be due to variability. 


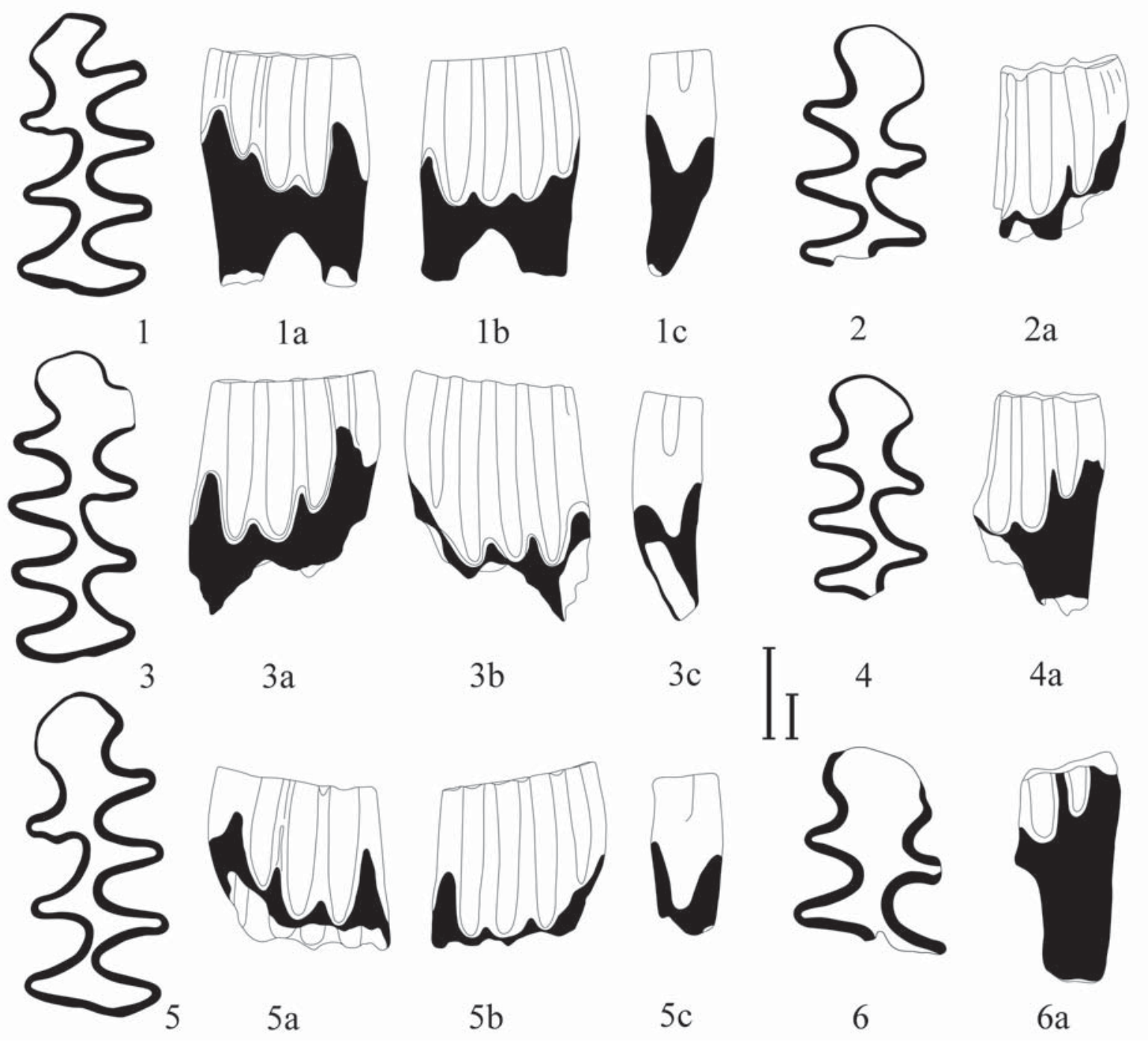

Figure 2. Ellobius tarchancutensis, first lower molars (m1). 1 - sin, 139/21; 2 - dex, 139/24; 3 - dex, 139/22; 4 - dex, 139/01; 5 - sin, 139/23; 6 - dex, 139/30 (a - labial view, b lingual view, c - posterior view). Scale bars are $1 \mathrm{~mm}$.

Ellobius tsharynensis Tjutkova, 1989. This form from southern Kazakhstan is close to the described form in size, hypsodonty and confluence degree of occlusal elements. It, however, differs in deeper BRA3 and the presence of Mimomys-ridge.

Comments. The name Ellobius kujalnikensis Topachevsky, 1965a has priority over Ellobius palaeotalpinus Schevtschenko, 1965 due to earlier publication date (February 17) of the former than the latter (March 24). All characters of E. tiliguliensis Topachevsky et Recovets, 1982 fall in the variability range of $E$. $k u$ jalnikensis.

The synonymy and scope of Early Pleistocene taxa of smaller mole voles depend on the age of the split between the two modern well separated species, western E. talpinus and eastern E. tancrei Blasius. It is reasonable to suppose a chronological stage of a single ancestral species and a subsequent geographic allopatric speciation event. According to the molecular clock estimates based on nuclear genes, both lineages separated not earlier than latest Pliocene and Early Pleistocene between ca. 2.1-1.0 Ma (Abramson et al., in press). First smaller mole voles appear in fossil record in this very interval. Latest Pliocene and Early Pleistocene Ellobius from Eastern Europe and Kazakhstan are quite similar in dental morphology. We formally regard Ellobius kujalnikensis from the Black Sea region and Latest Pliocene Ellobius tsharynensis from southern Kazakhstan as ancestral stages of the common and eastern mole voles, respectively. The phyletic lineage leading to the modern Ellobius talpinus includes successive chronospecies with Late Pliocene-Early Pleistocene Ellobius kujalnikensis (prismatic fold typically present, $\mathrm{HH}$-index of $\mathrm{m} 1$ less than 1.5 ), early 
Table 1. Measurements and indices of Ellobius tarchancutensis, m1, Sarkel.

\begin{tabular}{|l|l|l|l|l|l|l|l|}
\hline & \multicolumn{1}{|c|}{$\mathrm{n}$} & \multicolumn{1}{c|}{ Mean } & \multicolumn{1}{c|}{ SE } & \multicolumn{1}{c|}{ Minimum } & \multicolumn{1}{c|}{ Maximum } & \multicolumn{1}{c|}{ SD } & CV \\
\hline LENGTH & 3 & 3.32 & 0.1364 & 3.05 & 3.50 & 0.2363 & 7.12 \\
\hline WIDTH & 6 & 1.42 & 0.0413 & 1.30 & 1.55 & 0.1011 & 7.11 \\
\hline L_ANTR & 6 & 1.49 & 0.0638 & 1.30 & 1.65 & 0.1563 & 10.48 \\
\hline ASD & 7 & 2.99 & 0.2577 & 1.50 & 3.50 & 0.6817 & 22.83 \\
\hline HSD & 5 & 2.12 & 0.1329 & 1.65 & 2.35 & 0.2971 & 14.01 \\
\hline HSLD & 3 & 1.55 & 0.0289 & 1.50 & 1.60 & 0.0500 & 3.23 \\
\hline HH-INDEX & 3 & 1.37 & 0.0667 & 1.30 & 1.50 & 0.1155 & 8.45 \\
\hline HSD/L & 3 & 0,47 & 0,0202 & 0,44 & 0,51 & 0,0350 & 7,47 \\
\hline A/L & 3 & 3.68 & 0.0928 & 3.50 & 3.80 & 0.1607 & 4.36 \\
\hline
\end{tabular}

Middle Pleistocene Ellobius melitopoliensis Topachevsky, 1973 (prismatic fold variably present, $\mathrm{HH}$-index of $\mathrm{m} 1$ ranges between 1.5 and 3), and late Middle Pleistocene - recent Ellobius talpinus (prismatic fold strongly reduced, HH-index more than 5). Late Middle Pleistocene Ellobius tschernojaricus Alexandrova, 1976, showing certain archaic features, is currently included in the modern form. E. talpinus is the most hypsodont species of the lineage. The Sarkel smaller mole vole in size, morphology, and hypsodonty level is most similar to E. kujalnikensis.

\section{Subgenus Bramus Pomel, 1892}

1890 Bramus: Pomel: $1159-1163$

1965a Afganomys: Topachevsky: 98

Type species. Bramus barbarus Pomel, 1892

Description. This subgenus is distinct from the nominative subgenus in larger size, phyletic trends to elongation of $\mathrm{m} 1$, complication of M2 (development of LRA1), and more complex and elongated (less reduced) M3. Cranial differences include well-developed interorbital crest and obliteration of the very small interparietal in older individuals.

Comments. The name Bramus Pomel, 1892 is the valid senior synonym of Afganomys Topachevsky, 1965. The marked differentiation of Ellobiusini is apparent in external morphology (Topachevsky, 1965a; Pozdnyakov, 2008), karyology (Borisov et al., 1991), biochemical (Mezhzherin et al., 1995), and molecular genetic markers (Conroy \& Cook, 1999). Two groups most likely separated not later than early Late Pliocene and probably deserve the status of full genera.

Ellobius(Bramus) tarchancutensis Topachevsky, 1963 Figs 2-5, Tabs 1-4.

1963: Ellobius tarchancutensis sp. nov.: V.A. Topachevsky, Novi vidy...: pp. 100-103.

1965a: Ellobius tarchancutensis: V.A. Topachevsky, Nasekomoyadnye i gryzuny...: pp. 97-100, fig.23: 1-2.

1973: Ellobius (cf. Afghanomys) tarchancutensis: V.A. Topachevsky, Gryzuny tamanskogo...: pp. 134-149, figs.31-35.

Material. $7 \mathrm{~m} 1 ; 10 \mathrm{~m} 2 ; 1 \mathrm{~m} 3 ; 4 \mathrm{M} 1 ; 2 \mathrm{M} 2 ; 8 \mathrm{M} 3$.
Locality and geological age. Sarkel, Rostov Region, Russia. Early Pleistocene, early Biharian, Tamanian faunal assemblage, regional zone MQR8.

Description. Large vole. Dental elements characteristically alternate. Most occlusal elements communicate by dentine spaces equal to one or two widths of the enamel. Enamel is uniformly thick. Dentine tracts are moderately developed.

m1 (Fig. 2, Tab. 1): Basic triangles (T1-T3) strongly alternate. $\mathrm{T} 1$ and $\mathrm{T} 2$ show wider confluence than $\mathrm{T} 2$ and T3. Anteroconid elements are broadly fused. Anteroconid cap is rounded. In one specimen (Fig. 2: 3) it bears a shallow antero-labial fold. Posterior wall in T4 frequently bears a flexure (Fig. 2: 1-3, 5) reminiscent of strongly reduced Mimomys-ridge. Dentine tracts are relatively low (Tab. 1). The tract of T4 (prismosinuid)

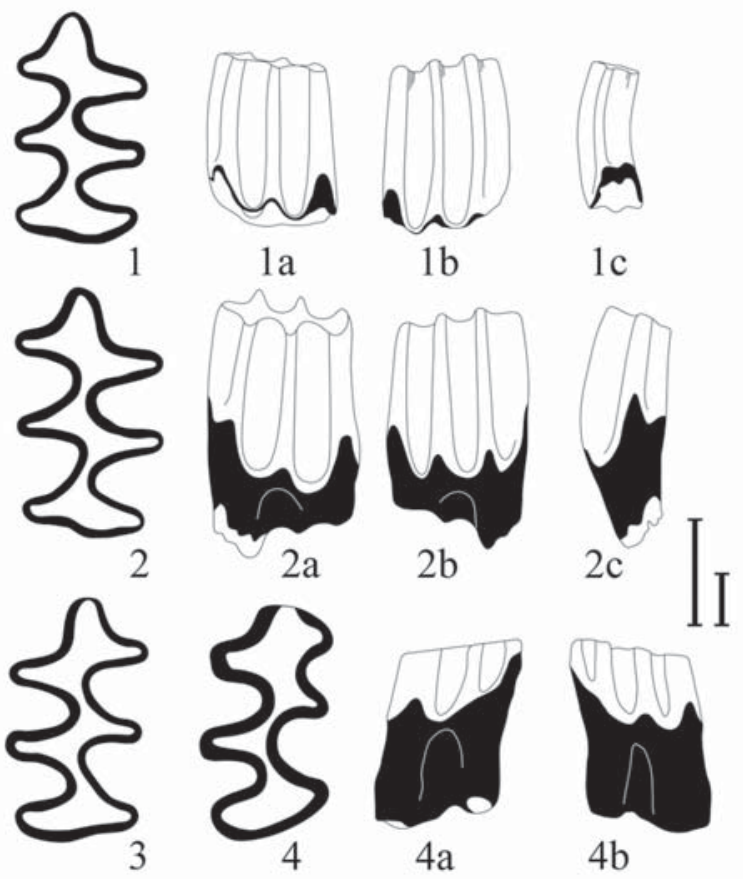

Figure 3. Ellobius tarchancutensis, lower molars. $1-\mathrm{m} 2$, sin, 139/03; $2-\mathrm{m} 2$, sin, 139/04; $3-\mathrm{m} 2$, dex, 139/25; 4 - m3, dex, 139/09 (a - labial view, b - lingual view, c anterior view). Scale bars are $1 \mathrm{~mm}$. 
Table 2. Measurements and indices of Ellobius tarchancutensis, m2, Sarkel.

\begin{tabular}{|l|l|l|l|l|l|l|l|}
\hline & \multicolumn{1}{|c|}{$\mathrm{n}$} & Mean & SE & Minimum & Maximum & SD & CV \\
\hline LENGTH & 8 & 2.23 & 0.0294 & 2.07 & 2.30 & 0.0294 & 3.73 \\
\hline WIDTH & 10 & 1.27 & 0.0281 & 1.20 & 1.50 & 0.0281 & 6.98 \\
\hline ASD & 7 & 1.35 & 0.0664 & 1.00 & 1.50 & 0.0664 & 13.01 \\
\hline HSD & 9 & 1.17 & 0.0624 & 0.85 & 1.45 & 0.0624 & 16.04 \\
\hline HSLD & 8 & 1.05 & 0.0433 & 0.90 & 1.25 & 0.0433 & 11.66 \\
\hline HH-INDEX & 8 & 1.55 & 0.0660 & 1.24 & 1.88 & 0.0660 & 12.03 \\
\hline HSD/L & 7 & 0.51 & 0.0322 & 0.40 & 0.63 & 0.0322 & 16.73 \\
\hline
\end{tabular}

is lower than anterosinuid. Lower edge of enameldentine juncture on posterior prism is distinctly higher than bases of main labial reentrants. Two roots are present. In posterior view (Fig. 2: 1c) the crown and roots curve labially indicating the position of the tooth labial to the incisor.

m2 (Fig. 3: 1-3; Tab. 2): Antero-lingual reentrant (LRA3) is well developed. It is deeper in young specimens and gets shallower with wear. Prismosinuid (tract of BSA3) is well developed as indentation of ASD. The postero-lingual reentrant (LRA1) runs to the crown base showing no tight contact of the molar with the lower incisor and completely reached pleurorhizal condition. Two roots are fused near the crown base and become separate in older individuals.

m3 (Fig. 3: 4): $2.2 \times 1.15$. BRA2 is shallower and less deep down the crown than BRA1. T1 and T2 are well separated and alternate. T2 is broadly confluent with T3. Dentine tracts: $\mathrm{ASD}=1.0, \mathrm{HSD}=0.35, \mathrm{HSLD}=$ 0.5 . Roots are broadly confluent but still discernible as individual shafts.

M1 (Fig. 4: 1-2, Tab. 3). Occlusal elements distinctly alternate with T1-T2 being the most confluent triangles. Anterosinulus (ASL) is distinctly higher than protosinus (PRS). Hyposinus (tract of LSA3) is well developed. The lingual (protocone) root occurs as a strongly reduced rootlet.

M2 (Fig. 4: 3): $2.3 \times 1.3$. LRA1 is relatively shallow. Anterosinus is much higher than protosinus (AS=1.05, $\mathrm{PRS}=0.35) . \mathrm{DS}=1.15$. Two roots are present.

M3 (Fig. 5, Tab. 4). The molar is composed of the anterior (AC + T2) and posterior (variably differentiated T3, T4) lobes. The T2-T3 occlusal connection is the narrowest one. The posterior lobe gets less dissected with wear. Two separate unfused roots are present.

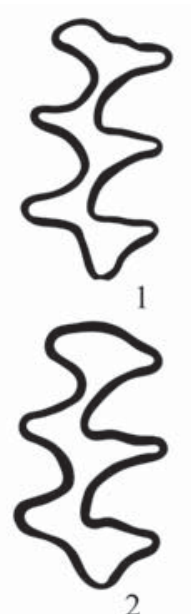

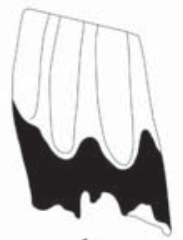

la

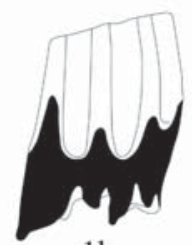

$1 \mathrm{~b}$

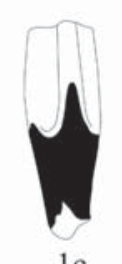

$1 \mathrm{c}$

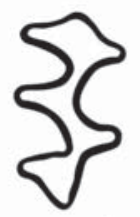

3

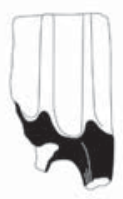

$3 \mathrm{~b}$

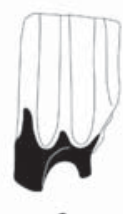

$3 \mathrm{a}$

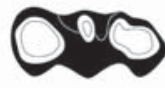

$1 d$

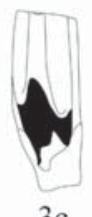

$3 \mathrm{c}$
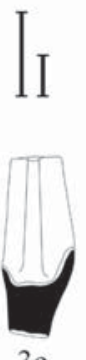

$3 \mathrm{e}$
Figure 4. Ellobius tarchancutensis, upper molars.

1 - M1, sin, 139/12; 2 - M1, sin, 139/35; 3 - M2, dex, 139/28 (a - labial view, b - lingual view, c - posterior view; $\mathrm{d}-$ root view, e - anterior view). Scale bars are $1 \mathrm{~mm}$.

Comparison. Ellobius primigenius Savinov, 1974: is the most primitive among known forms of Ellobius (Bramus) (Lytchev \& Savinov, 1974; Tutkova, 1989). It is also the oldest in geological age (Late Pliocene). Dentine tracts are very low. In all characters this form is

Table 3. Measurements and indices of Ellobius tarchancutensis, M1, Sarkel.

\begin{tabular}{|l|l|l|l|l|l|l|l|}
\hline & \multicolumn{1}{|c|}{$\mathrm{n}$} & Mean & SE & Minimum & Maximum & SD & CV \\
\hline LENGTH & 2 & 3.02 & 0.0250 & 3.00 & 3.05 & 0.0354 & 1.17 \\
\hline WIDTH & 4 & 1.58 & 0.0520 & 1.45 & 1.70 & 0.1041 & 6.61 \\
\hline DS & 2 & 1.40 & 0.1000 & 1.30 & 1.50 & 0.1414 & 10.10 \\
\hline AS & 4 & 1.04 & 0.1068 & 0.90 & 1.35 & 0.2136 & 20.59 \\
\hline ASL & 3 & 1.33 & 0.0601 & 1.25 & 1.45 & 0.1041 & 7.81 \\
\hline PRS & 4 & 1.01 & 0.0921 & 0.80 & 1.25 & 0.1843 & 18.20 \\
\hline PA-INDEX & 4 & 1.46 & 0.1106 & 1.20 & 1.68 & 0.2212 & 15.18 \\
\hline
\end{tabular}



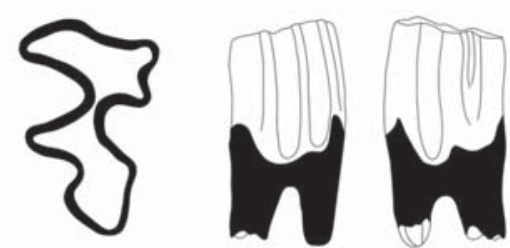

1

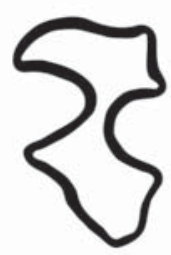

1a

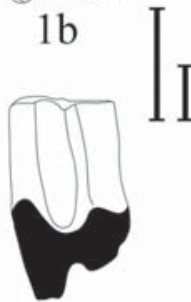

3

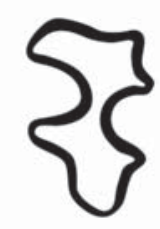

5

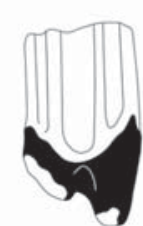

$3 \mathrm{a}$

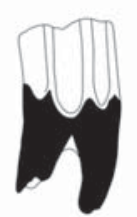

$5 \mathrm{a}$
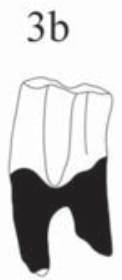

$5 b$

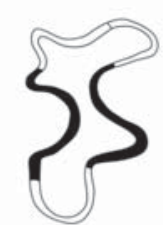

2

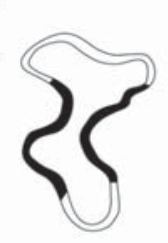

4

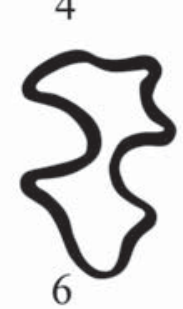

Figure 5. Ellobius tarchancutensis, third upper molars (M3). 1 - sin, 139/15; 2 - dex, 139/29; 3 - sin, 139/16; 4 - sin, 139/ 36; $5-\sin , 139 / 17 ; 6-\sin , 139 / 38$. Scale bars are $1 \mathrm{~mm}$.

plesiomorphic with regard to Pleistocene forms of the subgenus.

Ellobius lakhutensis Zazhigin, 1988: more hypsodont than E. tarchancutensis but has shorter anteroconid complex, and more confluent occlusal elements. Mosaic combination of advanced and primitive characters indicates a different lineage.

Ellobius fuscocapillus (Blyth, 1843): Much more hypsodont than E. tarchancutensis. Occlusal elements in $\mathrm{m} 1$ show pairwise confluence of $\mathrm{T} 1-\mathrm{T} 2$ and $\mathrm{T} 3-\mathrm{T} 4$, and T5-AC.

Ellobius tarchancutensis: the type sample from Tarkhankut (=Tarchancut) shows somewhat lower dentine tracts (HH-index 1.35-1.5-1.8, $\mathrm{n}=7$ versus 1.98 , 2.02, 2.19 in Sarkel) and simpler structure of M3 with less developed T3 and shorter posterior lobe of this tooth. It is probably an indication of an older age of the Tarkhankut locality compared to that of Sarkel. This relationship is also evident in pairwise comparison of a

number of conspecific voles from both sites. At the current stage of knowledge, given the limited material from the Lower Don site, I refrain from describing a separate chronotaxon based on the form from Sarkel.

The single molar of $E$. tarchancutensis from Nesmeyanovka (Early Pleistocene Lower Don region) locality is indistinguishable from the type sample in size, morphology, and hypsodonty.

The single fragmentary $\mathrm{m} 1$ of this species from Early Pleistocene level of Zhevakhova Gora 9 (Topachevsky \& Rekovets, 1982) has a very low ASD=1.0. It is the oldest known occurrence of larger mole voles in Eastern Europe.

Ellobius lutescens Thomas, 1897: much more hypsodont form; $\mathrm{m} 1$ with almost opposing $\mathrm{T} 1$ and $\mathrm{T} 2$, and alternating but broadly fused T3 and T4 (T1-T4 markedly alternate in the Tarchankut mole vole), the T3-T4 confluence $>=\mathrm{T} 4-\mathrm{T} 5$ (the condition reversed with regard to E. tarchancutensis).

Ellobius africanus Jaeger, 1988: no marked differences detected in size, hypsodonty, and occlusal morphology. Noteworthy is relatively poorly developed LRA1 in M2 of both forms. E. tarchancutensis and E. africanus may well be conspecific thus marking the extensive dispersal of larger mole voles throughout the Caucasus, Anatolia, Near East, and North Africa at the beginning of Early Pleistocene.

Ellobius atlanticus Jaeger, 1988: this endemic North African form shows a strong development of morphological trends apparent in E. ex gr. tarchancutensisafricanus. The most obvious is the very deep LRA1 in M2. At the same time, it retains relatively low dentine tracts. It indicates the endemicity of the North African lineage E. africanus-E. atlanticus-E.barbarus. The advanced forms of the African lineage show a marked size increase of cheek dentition (Jaeger, 1988; Geraads, 1994).

\section{Discussion}

The occurrence of larger mole voles Ellobius (Bramus) outside their present range in the lowland biotopes of south East Europe in Early Pleistocene is an interesting fact. Currently, there are five locations of the group in Eastern Europe: Tarchankut in Crimea, Zhevakhova Gora in Odessa Region (Topachevsky \& Rekovets, 1982), Nesmeyanovka and Sarkel (lower Don area),

Table 4. Measurements and indices of Ellobius tarchancutensis, M3, Sarkel.

\begin{tabular}{|l|l|l|l|l|l|l|l|}
\hline & \multicolumn{1}{|c|}{$\mathrm{n}$} & \multicolumn{1}{|c|}{ Mean } & \multicolumn{1}{c|}{ SE } & \multicolumn{1}{c|}{ Minimum } & \multicolumn{1}{c|}{ Maximum } & \multicolumn{1}{c|}{ SD } & CV \\
\hline LENGTH & 6 & 1.87 & 0.0477 & 1.75 & 2.00 & 0.1169 & 6.26 \\
\hline WIDTH & 8 & 1.21 & 0.0263 & 1.10 & 1.35 & 0.0744 & 6.14 \\
\hline DS & 8 & 0.38 & 0.0134 & 0.35 & 0.45 & 0.0378 & 10.08 \\
\hline AS & 8 & 0.38 & 0.0134 & 0.35 & 0.45 & 0.0378 & 10.08 \\
\hline ASL & 6 & 0.76 & 0.0676 & 0.50 & 1.00 & 0.1656 & 21.83 \\
\hline PA_INDEX & 6 & 0.99 & 0.0635 & 0.71 & 1.14 & 0.1556 & 15.66 \\
\hline LP/L & 6 & 43.40 & 1.0694 & 40.00 & 47.22 & 2.6194 & 6.04 \\
\hline
\end{tabular}


and Akkulaevo 2 in southern Urals (Suchov, 1970). Zazhigin (1980) mentioned Ellobius cf. tarchancutensis in Early Pleistocene locality of Razdolie in southeastern West Siberia. Biochronologically, larger mole voles were present in East Europe from the beginning to the middle part of Early Pleistocene, regional zones MQR10-MQR8. This is a considerable time spanning about 1 myr. During this time, the lineage manifests dental evolution towards higher hypsodonty. In addition to Tarkhankut, Sarkel is only second European locality that yielded serial material on this group during last five decades. States of dental characters in fossil East European larger mole voles are more plesiomorphic with respect to those in modern species of Ellobius (Bramus). Among these features are lower level of hypsodonty, marked alternation and separation of molar triangles, signs of the Mimomys-ridge. Certain characters, as marked anteroconid elongation and complex morphotypes of M3 tentatively indicate affinities with Transcaucasian mole vole, Ellobius lutescens. The similar hypsodonty levels of earliest East European (Ellobius tarchancutensis) and North African (Ellobius africanus) forms indicate that the range expansion to Africa could have occurred no later than mid Early Pleistocene.

Similarity of East European forms with the modern Transcaucasian mole vole implies south-north range expansion, rather than east-west dispersal. Though, the presence of Ellobius (Bramus) sp. in Early Pleistocene of southern Urals (Suchov, 1970) may indicate the eastward range expansion of the European form. More sites with ample material are needed to elucidate morphological trends and affinities of Ellobius (Bramus) tarchancutensis.

The biological success of larger mole voles in Eastern Europe was apparently associated with the combination of warm climate and expansion of open steppelike landscapes. Same conditions facilitated the expansion of the group to Middle East and North Africa. The subsequent endemic evolution of the group in North Africa in Early through Middle Pleistocene (Jaeger, 1986, Geraads, 2002), which mimics morphological trends in the Asian home range, provides an excellent example of parallelisms in mammals. The considerable climatic cooling in the region at the Early-Middle Pleistocene transition could cause the disappearance of $\mathrm{Bra}$ mus in Eastern Europe by late Early Pleistocene. Likewise, the extinction of the North African Bramus lineage in late Middle Pleistocene is believed to be associated with climate-based environmental fluctuations (Jaeger, 1988) or, according to the opinion of D. Geraads, with a drastic aridization and a possible competition with gerbils.

The Sarkel material of nominative subgenus of Ellobius confirms the constant presence of this group in the southeastern part of Europe since Late Pliocene through Early Pleistocene to the present. Mid Early Pleistocene Ellobius (Ellobius) kujalnikensis in Sarkel shows a number of primitive characters common among broad- ly synchronous samples from the region. Most typical are very low hypsodonty and weak reduction of third molars.

Mole voles in the Sarkel fauna co-occur with other obligate fossorial small mammals as Spalax minor and Talpa. Characteristic high diversity of Early Pleistocene faunas in the south of East Europe indicates mosaic environment combining closely spaced steppe-like, meadow, desert, and wooded biotopes under conditions of relatively warm climate.

ACKNOWLEDGEMENTS. I thank Vadim Titov, Pavel Nikolskyi, Alexander Borodin, Tatiana Strukova, and late Andrey Dodonov for valuable discussions and joint work in the field; Natalia Serdyuk, Maria El'kina, Sergey Zykov, and Valeriy Stakheev for the great help during the filed season of 2007; Denis Geraads kindly provided comparative material on fossil African mole voles and made valuable comments on stratigraphic position of these forms. This work was supported by the Russian Foundation for Basic Research, projects nos. 06-05-64049, 07-05-00400.

\section{References}

Abramson N.I., Lebedev V.S., Bannikova A.A. \& Tesakov A.S. In press. Radiation stages in phylogeny of voles (Arvicolinae, Rodentia): data on nuclear genes // Doklady Biological Sciences.

Borisov Y.M., Lyapunova E.A. \& Vorontsov N.N. 1991. [Karyotype evolution in the genus Ellobius (Microtinae, Rodentia)] // Genetika. Vol. 27. No.3. P.523-532 [in Russian].

Conroy C.J. \& Cook J.A. 1999. MtDNA evidence for repeated pulses of speciation within arvicoline and murid rodents // Journal of Mammalian Evolution. Vol.6. No.3. P.221-245.

Dodonov A.E., Tesakov A.S., Titov V.V., Inozemtsev S.A., Simakova A.N., Nikolsky P.A. \& Trubikhin V.M. 2007. [New data on the stratigraphy of Pliocene-Quaternary deposits of lower Don area: sections along coasts of Tsymla Reservoir] // Gladenkov Yu.B. (ed.). [Geological events of Neogene and Quaternary of Russia: modern stratigraphic schemes and paleogeographic reconstructions]. Moskva: Geos. P.43-53 [in Russian].

Geraads D. 1994. Rongeurs et lagomorphes du Pléistocène moyen de la "Grotte des Rhinocéros", carrière Oulad Hamida 1, à Casablanca, Maroc // Neues Jahrbuch für Geologie und Paläontologie, Abhandlungen. Vol.191. No.2. P.147-172.

Geraads D. 2002. Plio-Pleistocene mammalian biostratigraphy of Atlantic Morocco // Quaternaire. Vol.13. No.1. P.43-53.

Gromov I.M. \& Polyakov I.Ya. 1977. [Voles (Microtinae). Fauna of the USSR Mammals]. Leningrad: Nauka. Vol.3. No.8. 504 p. [In Russian].

Hinton M.A.C. 1926. Monograph of the Voles and Lemmings (Microtinae) Living and Extinct. London: British Museum (Natural History). Vol.1. 488 p.

Jaeger J.-J. 1988. Origine et évolution du genre Ellobius (Mammalia, Rodentia) en Afrique Nord-Occidentale // Folia Quaternaria. Vol.57. P.3-50. 
Kretzoi M. 1969. Skizze einer Arvicoliden Phylogenie-Stand // Vertebrata Hungarica. Vol.11. Nos.1-2. P.155-192.

Lytchev G.F. \& Savinov P.F. 1974. [Late Pliocene lagomorphs and rodents from Kiikbai] // Materialy po Istorii i Faune Kazakhstana. Vol.6. P.39-57 [in Russian].

Meulen A. van der. 1973. Middle Pleistocene smaller mammals from the Monte Peglia (Orivieto, Italy) with special reference to the phylogeny of Microtus (Arvicolidae, Rodentia) // Quaternaria. Vol.17. P.1-144.

Mezhzherin S.V., Morozov-Leonov S.Yu. \& Kuznetsova I.A. 1995. [Biochemical variation and genetic divergence in Palearctic voles (Arvicolidae): subgenus Terricola, true lemmings Lemmus Link 1975, collared lemmings Dicrostonyx Gloger 1841, stepe lemmings Lagurus Gloger 1842, mole voles Ellobius Fischer von Waldheim 1814] // Genetika. Vol.31. No.6. P.788-797 [in Russian].

Nikolskii P.A. \& Tesakov A.S. 2003. [Sarkel: new locality of Tamanian theriofauna in the Lower Don region] // [Mammal Fauna of Russia and Adjacent Areas.] Moskva: Teriologicheskoe Obshchestvo. P.236 [in Russian].

Pomel A. 1892. Sur le Bramus, nuveau type de rongeurs fossile des phosphorites quaternaires de la Berbérie // Comptes Rendus de l'Academie des Sciences. No.114. P.1159-1169.

Pozdnyakov A.A. 2008. The bony palate morphology in Arvicolinae (Rodentia, Cricetinae) with comments on taxonomy and nomenclature // Trudy Zoologicheskogo Muzeya Moskovskogo Gosudarstvennogo Universiteta. Vol.49. P.184-209 [in Russian, with English summary].

Rabeder G. 1981. Die Arvicoliden (Rodentia, Mammalia) aus dem Pliozän und dem älterem Pleistozän von Niederösterreich // Beitrage zur Paläontologie von Österriech. No.8. 343 p.

Schevtschenko A.I. 1965. [Key complexes of small mammals from Pliocene and lower Anthropogene in the southwestern part of the Russian Plain] // Nikiforova K.V. (ed.). [Stratigraphic Significance of Anthropogene Fauna of Small Mammals]. Moskva: Nauka. P.7-57 [in
Russian].

Suchov V.P. 1970. [Late Pliocene small mammals of Akkulaevo locality in Bashkiria]. Moskva: Nauka. 93 p. [in Russian].

Tesakov A.S. 2004. [Biostratigraphy of Middle Pliocene Eopleistocene of Eastern Europe (based on small mammals)]. Moskva: Nauka. 247 p. [in Russian].

Tjutkova L.A. 1989. [New species of mole vole (Rodentia) from Late Pliocene of south-western Kazakhstan] // Paleontologicheskii Zhurnal. No.2. P.112-115 [in Russian].

Topachevsky V.A. 1963. [New vole species (Rodentia, Microtinae) from the Upper Pliocene and Lower Anthropogene deposits of the southern Ukraine and Crimea] // Dopovidi Akademii Nauk Ukrainskoi SSR. No.1. P.100103 [in Ukrainian].

Topachevsky V.A. 1965a. [Insectivores and Rodents of the Late Pliocene Fauna of Nogaisk]. Kiev: Naukova Dumka. 163 p. [in Russian].

Topachevsky V.A. 1965b. [New species of mole voles of the genus Ellobius Fischer (Rodentia, Microtinae) from the upper Pliocene deposits of the southern Ukraine and Crimea] // Dopovidi Akademii Nauk Ukrainskoi SSR. No.4. P.515-517 [in Ukrainian].

Topachevsky V.A. 1973. [Rodents of the Tamanian Faunal Complex of Crimea]. Kiev: Naukova Dumka. 235 p. [in Russian].

Topachevsky V.A. \& Rekovets L.I. 1982. [New materials for taxonomy and evolution of Ellobius s.str. (Rodentia, Cricetidae)] // Vestnik Zoologii. No.5. P.47-54 [in Russian].

Zazhigin V.S. 1980. [Late Pliocene and Anthropogene Rodents of the South of Western Siberia]. Moskva: Nauka. 155 p. [in Russian].

Zazhigin V.S. 1988. [Paleontological descriptions: Insectivora, Lagomorpha, Rodentia] // Vangengeim E.A. \& Nikiforova K.V. (eds.). [Biostratigraphy of Late PlioceneEarly Pleistocene of Tadzhikistan (Mammalian Fauna)]. Moskva: Nauka. P.18-24 [in Russian]. 